\title{
Jean-Pierre Bordier, Planter le décor: arbres de théâtre
}

\author{
Maria Colombo Timelli
}

\section{(2) OpenEdition}

\section{Journals}

\section{Édition électronique}

URL : http://journals.openedition.org/studifrancesi/5554

DOI : 10.4000/studifrancesi.5554

ISSN : 2427-5856

\section{Éditeur}

Rosenberg \& Sellier

\section{Édition imprimée}

Date de publication : 1 septembre 2011

Pagination : 393

ISSN : 0039-2944

\section{Référence électronique}

Maria Colombo Timelli, « Jean-Pierre Bordier, Planter le décor: arbres de théâtre », Studi Francesi [En ligne], 164 (LV | II) | 2011, mis en ligne le 30 novembre 2015, consulté le 11 janvier 2021. URL : http:// journals.openedition.org/studifrancesi/5554; DOI : https://doi.org/10.4000/studifrancesi.5554

\section{Ce document a été généré automatiquement le 11 janvier 2021.}

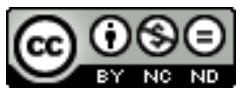

Studi Francesi è distribuita con Licenza Creative Commons Attribuzione - Non commerciale - Non opere derivate 4.0 Internazionale. 


\title{
Jean-Pierre Bordier, Planter le décor: arbres de théâtre
}

\author{
Maria Colombo Timelli
}

\section{RÉFÉRENCE}

JEAN-PIERRE BORDIER, Planter le décor: arbres de théâtre, in: Valérie FASSEUR, Danièle JAMESRAOUL et Jean-René VALETTE (dir.), L'arbre au Moyen Âge, Paris, PUPS, 2010, pp. 139-150.

Ce sont les aspects techniques de la question qui retiennent l'attention de Jean-Pierre Bordier: il s'agit d'interroger quelques pièces théâtrales de l'extrême fin du Moyen Âge (mystères et sotties), ainsi que de rares documents d'archives, afin de comprendre si les arbres auxquels les répliques font allusion étaient bien des arbres naturels plantés sur scène, ou des arbres artificiels, enfoncés dans les planches, ou encore des arbres figurés sur des toiles peintes. Même si le théâtre médiéval ne visait aucun réalisme, aucun effet d'illusion, il est hors de doute que certains arbres - tel le figuier du suicide de Judas, dans la Passion de Valenciennes - jouaient un rôle essentiel à l'action, ce qui imposait la prise en charge de quelques aspects matériels non secondaires. 